\title{
Carbohydrate Antigen 19-9 Is a Prognostic Factor Which Correlates With HDAC1 and HIF-1 $\alpha$ for Intrahepatic Cholangiocarcinoma
}

\author{
SHOGO OHTA ${ }^{1}$, YUJI MORINE ${ }^{1}$, SATORU IMURA ${ }^{1}$, TETSUYA IKEMOTO ${ }^{1}$, \\ YUSUKE ARAKAWA $^{1}$, SHUICHI IWAHASHI ${ }^{1}$, YU SAITO $^{1}$, SHINICHIRO YAMADA ${ }^{1}$, \\ YUMA WADA $^{1}$, SHOKO YAMASHITA ${ }^{1,2}$, YOSHIMI BANDO ${ }^{2}$ and MITSUO SHIMADA ${ }^{1}$ \\ ${ }^{1}$ Department of Surgery, Institute of Biomedical Sciences, \\ Tokushima University Graduate School, Tokushima, Japan; \\ ${ }^{2}$ Division of Pathology, Tokushima University Hospital, Tokushima, Japan
}

\begin{abstract}
Background/Aim: Carbohydrate antigen 19-9 (CA19-9) is a poor prognostic marker in intrahepatic cholangiocarcinoma (IHCC). Previous studies have shown a link between hypoxia and CA19-9 in cancer, and we have previously demonstrated a correlation between HDACl and $H I F-1 \alpha$ in IHCC. Here, we evaluated the expression and correlation of CA19-9 with HIF-1 and HDAC in IHCC. Patients and Methods: This study included 62 patients with IHCC who underwent primary hepatectomy at our department. Clinicopathological characteristics were examined. Immunohistochemical expression of HIF-1 and HDAC1 in specimens was quantitatively evaluated. Results: Patients with high preoperative serum CA19-9 levels showed clinicopathological characteristics associated with tumour progression. High CA19-9 levels were associated with worse overall and recurrence-free survival. Univariate and multivariate analysis detected high CA19-9 levels as an independent poor prognostic factor for IHCC. Serum CA199 was significantly correlated with both $\mathrm{HIF}-1 \alpha$ and $\mathrm{HDACl}$ expression. Conclusion: High serum CA19-9 level is a poor prognostic factor for overall survival in IHCC and correlates with HIF-1 $\alpha$ and HDACl expression.
\end{abstract}

Correspondence to: Mitsuo Shimada, MD, Ph.D., FACS, Associate Professor, Institute of Biomedical Sciences, Department of Surgery, Tokushima University Graduate School, 3-18-15 Kuramoto, Tokushima 770-8503 Japan. Tel: +81 886337137, Fax: +81 886319698, e-mail: mitsuo.shimada@tokushima-u.ac.jp

Key Words: Carbohydrate antigen 19-9, CA19-9, intrahepatic cholangiocarcinoma, IHCC, histone deacetylase, HDAC, hypoxia induced factor-1, HIF-1.
Intrahepatic cholangiocarcinoma (IHCC) is a common secondary hepatic tumour (1). Currently, the only effective treatment for IHCC is curative resection. However, in Japan, patients with IHCC who are treated with curative resection still show poor prognosis (2).

Carbohydrate antigen 19-9 (CA19-9), also known as sialyl Lewis a (sLea) antigen or cancer antigen $19-9$, is a cell surface marker (3) that is the most commonly validated tumour marker in several gastrointestinal cancers $(2,4-8)$. CA19-9 is a glycoprotein and cell adhesion molecule that binds E-selectin or P-selectin and its expression is related with metastasis and tumour embolism (9). CA19-9 also functions as a tumour marker for cholangiocarcinoma (10) and is a significantly poor prognostic marker in IHCC (4, $11,12)$. Some studies have indicated that high serum CA19-9 level is a poor prognostic factor after curative resection (11) and chemotherapy (12). However, no reports have investigated the correlation between serum CA19-9 levels and other biomarkers in malignancies of digestive organs.

Hypoxia enables tumour cells to grow rapidly via hypoxia induced factor-1 (HIF-1) expression. The HIF-1 transcription factor regulates the expression of genes involved in critical pathways in angiogenesis, tumour growth and metastasis (13). Previous studies have shown that CA19-9 is upregulated in hypoxia conditions. Hypoxia induces upregulation of sLea (CA19-9) synthesis via transcription of some related glycogens. Expression of sLea in cancer cell clones also promotes hypoxia resistance and the development of haematogenous metastasis in advanced stage cancer (14). In addition, HIF-1 also supports the emergence of cancer stem cells (CSCs). We have previously reported that increased expression of HIF- $1 \alpha$ is associated with increased tumour volume and poor prognosis in IHCC (15). 

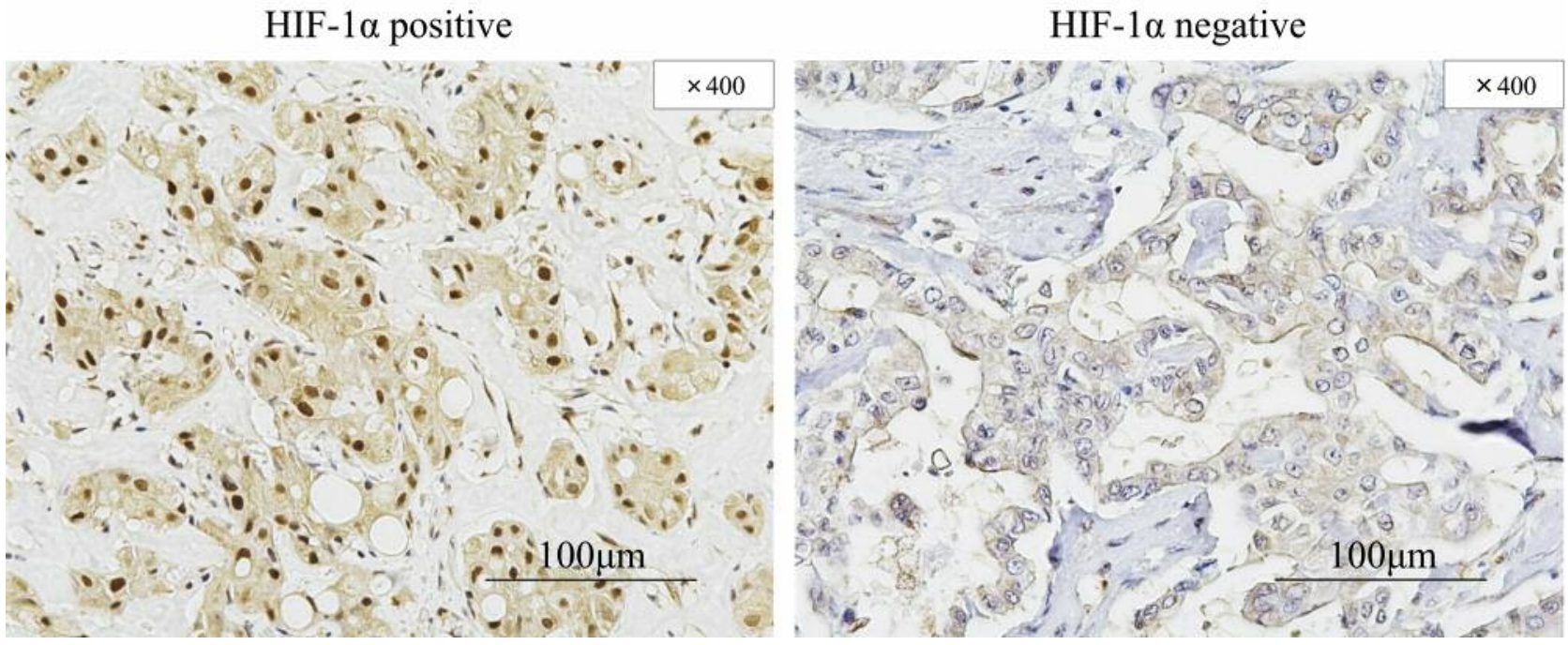

Figure 1. Detection of HIF-1 $\alpha$ in IHCC. HIF-1 $\alpha$ expression is localized in cancer cell nuclei. Representative images of HIF-1 $\alpha$ expression (positive and negative) in IHCC as determined by immunohistochemistry.

Histone deacetylases (HDACs) play an important role in regulating gene expression through the control of histone acetylation status and chromatin remodelling. Recent studies have shown that HDAC1 and HIF-1 $\alpha$ expression are significantly correlated with each other in pancreatic cancer (16). We have also previously reported the correlation between HDAC 1 and HIF- $1 \alpha$ in IHCC and cholangiocarcinoma cells (17) and demonstrated the correlation between HDAC1 and CSCs (18).

Based on these studies, we speculated that CA19-9 may correlate with HIF-1 and HDAC1 in IHCC. The aim of this study was to investigate the clinical significance of CA19-9 and its correlation with HIF-1 $\alpha$ and HDAC1 expression in IHCC.

\section{Patients and Methods}

Patients. Sixty-two patients with IHCC were enrolled in this study. All patients underwent primary hepatectomy with curative intent from January 1994 to December 2016 in our department. After hepatectomy, patients with pathological stage III or IV received adjuvant chemotherapy. The clinical stage, curability, T-grade and $\mathrm{N}$-grade were determined according to the Classification of Primary Liver Cancer by the Liver Cancer Study Group of Japan (19). Tgrade was based on tumour diameter $(>2 \mathrm{~cm} / \leq 2 \mathrm{~cm})$, tumour number $(\geq 2 /<2)$ and intrahepatic vascular infiltration (presence/none). The pathological findings including tumour differentiation (well/others) and other findings were diagnosed by the Department of Pathology in Tokushima University hospital. All clinical information was available in the hospital information system of our hospital. This study was approved by the Institutional Review Board of the Tokushima University Graduate School (approved ID number 3541) and all patients provided written informed consent.
Immunohistochemistry. Fifty IHCC tumour specimens were available for immunohistochemistry. Four-micrometre-thick sliced specimens were deparaffinized and rehydrated and endogenous peroxidase was blocked. The slides were incubated in Protein Serum Free (Dako, Burlington, Canada) for $10 \mathrm{~min}$ to prevent nonspecific antigen binding. Samples were incubated with primary antibody for $1 \mathrm{~h}$ at room temperature. Primary antibodies included anti-human HIF-1 $\alpha$ antibody (20960-1-AP, 1:100, Proteintech, Chicago, IL, USA) and anti-human HDAC1 antibody (sc-81598, 1:100; Santa Cruz, Paso Robles, CA, USA). The slides were incubated in secondary antibody EnVision Dual Link System-HRP (Dako) for $1 \mathrm{~h}$ at room temperature. Samples were developed in diaminobenzidine (Wako) and counterstained with Mayer's haematoxylin (No.3000-2, Muto Pure Chemicals Co. Ltd., Tokyo, Japan).

Stained slides were observed and evaluated by two pathologists. Both HIF- $1 \alpha$ and HDAC1 expression were detected in the nucleus. HIF- $1 \alpha$ positive expression was determined by counting the number of tumour cells in which $10 \%$ or more of the cells were positive (Figure 1), according to the previous report (17). HDAC1 expression was quantified by modified semiquantitative scoring as previously described (20) and scored as 0 (no staining), 1+ (weakly stained), $2+$ (moderately stained) and $3+$ (strongly stained). Samples with scores of $2+$ or $3+$ were defined as positive for HDAC1 expression (Figure 2).

Statistical analysis. Statistical calculations were performed using SPSS statistics version 24 64-bit Windows (IBM, Chicago, IL, USA). All clinical data were analysed by Mann-Whitney $U$-test or Fisher $U$-test. Overall survival (OS) and recurrence-free survival (RFS) were compared by Kaplan-Meier's curves and log-rank test. Univariate analysis was determined by $\log$-rank test. Multivariate analysis was evaluated by Cox hazard model. $p$-Value less than 0.05 was considered to indicate statistical significance. 

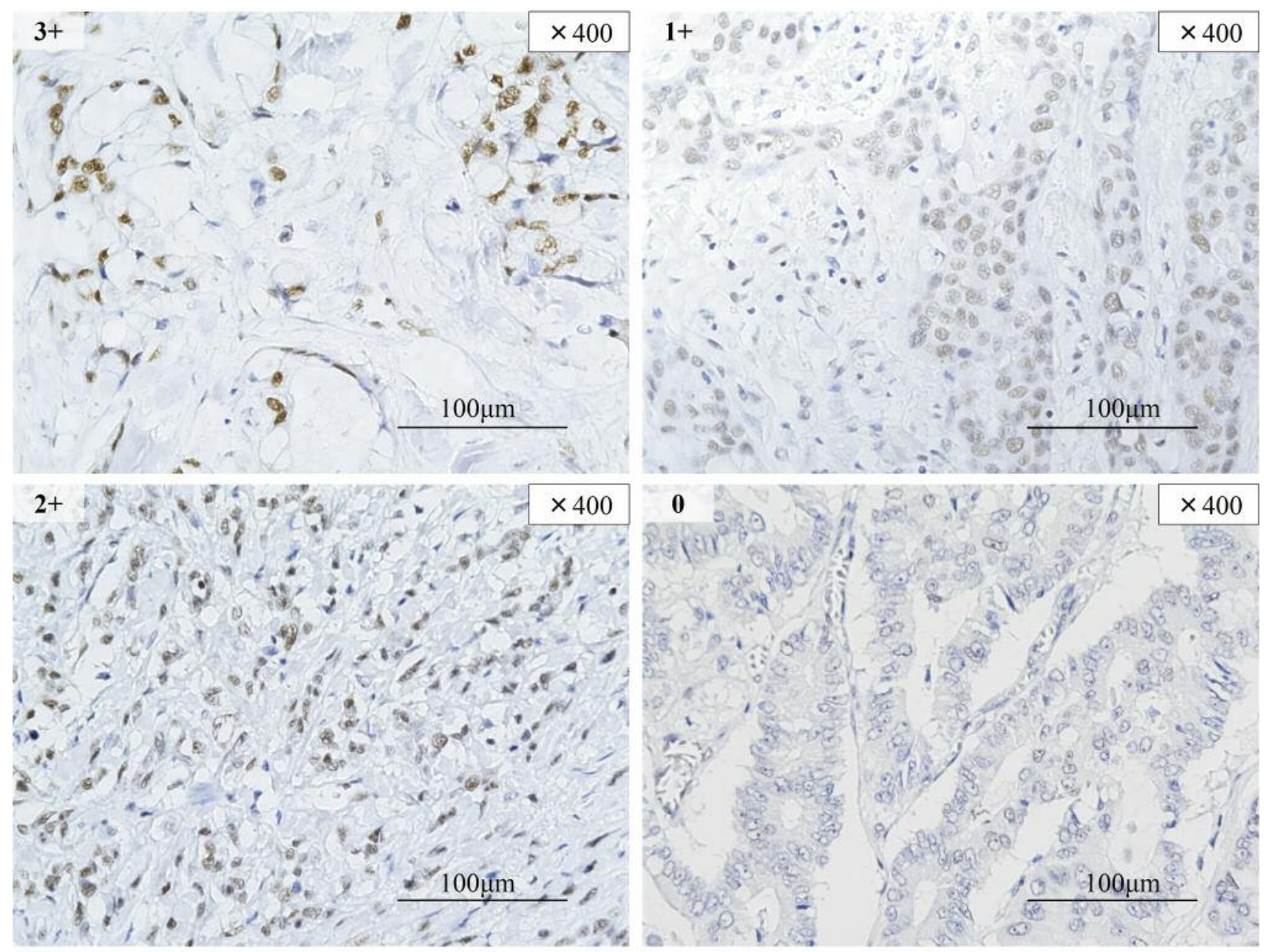

Figure 2. Detection of HDAC1 in IHCC. HDAC1 expression is localized in cancer cell nuclei. Representative images of HDAC1 expression (0 to $3+)$ in IHCC as determined by immunohistochemistry.

\section{Results}

CA19-9 is an independent poor prognostic factor in IHCC. This study included 62 patients with IHCC who underwent primary hepatectomy with curative intent at our department. The 62 patients were divided according to the preoperative serum CA19-9 level, as previously described (11), into the preoperative high serum CA19-9 group ( $>100$ $\mathrm{IU} / \mathrm{ml}, \mathrm{n}=31)$ or the low serum CA19-9 group $(<100 \mathrm{IU} / \mathrm{ml}$, $\mathrm{n}=31$ ). Table I shows the clinicopathological characteristics of both groups. The high CA19-9 group had significantly higher $\mathrm{T}$ grade $(p=0.007)$ and more advanced clinical stage $(p=0.043)$ than the low CA19-9 group. In pathological findings, the high CA19-9 group had more portal infiltration $(p=0.033)$ compared with the low CA19-9 group. There were no significant differences in the other clinicopathological characteristics. These results suggested that high serum CA19-9 levels correlated with tumour progression in IHCC.

Kaplan-Meier curves of OS (Figure 3) and RFS (Figure 4) were evaluated in the two groups. The high CA19-9 group had significantly poorer prognosis than the low CA19-9 group in both OS (5-year OS 9.4\% vs. 53.8\%, $p=0.002)$ and RFS (5-year RFS $10.8 \%$ vs. $27.0 \%, p=0.033$ ). Univariate analysis detected T grade $(p<0.001)$, lymph node metastasis $(p<0.001)$, advanced clinical stage $(p<0.001)$, pathological portal infiltration $(p=0.001)$ and high CA19-9 levels $(p=0.002)$ as significant poor prognostic factors for OS. Multivariate analysis detected only high CA19-9 level $(p=0.033)$ as an independent poor prognostic factor for OS (Table II), and advanced clinical stage $(p=0.016)$ was detected as an independent poor prognostic factor for RFS 


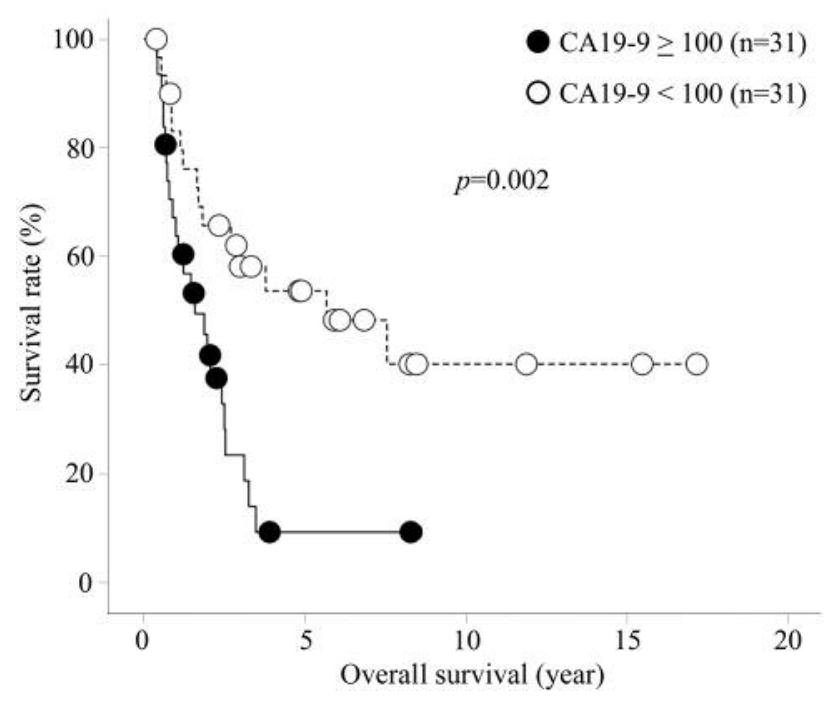

Figure 3. Kaplan-Meier curves of overall survival according to serum CA19-9 levels. Closed circles, CA19-9 high ( $\geq 100 \mathrm{IU} / \mathrm{ml})$ patients. Open circles, CA19-9 low (<100 IU/ml) patients. p-Value was calculated by the log-rank test.

(Table III). These results demonstrate that preoperative serum CA19-9 level is an independent poor prognostic factor for OS in IHCC.

Both HIF-1 $\alpha$ and HDACl expression correlated with serum CA19-9 level. Fifty of 62 specimens were available for evaluation in our dataset. HIF- $1 \alpha$-positive expression was detected in 23 IHCC patients. HDAC1 positive expression was detected in 19 IHCC patients. Figure 5 shows the correlations among HIF-1 $\alpha$, HDAC1 and serum CA19-9 levels. HIF- $1 \alpha$ and CA19-9 were significantly correlated with each other (positive $62.5 \%$ vs. negative $33.3 \%$, $p=0.041$ ) (Figure 5a). HDAC1 and CA19-9 were also significantly correlated with each other (positive $56.5 \% \mathrm{vs}$. negative 26.1\%, $p=0.036$ ) (Figure 5b).

Representative IHCC case. The representative IHCC case was a 71-year-old female. She underwent posterior segmentectomy for treatment of a single IHCC in the S6 segment. Preoperative CA19-9 levels were high (879 IU/l) and CEA levels were within normal limits $(4.5 \mathrm{ng} / \mathrm{ml})$. The diameter of the tumour was $1.8 \mathrm{~cm}$ (Figure 6). In pathological findings, there was only microscopic vessel infiltration and no other pathological findings. Almost 6 months later, remnant liver recurrence occurred and the patient underwent right lobectomy and caudal lobe partial resection. However, soft tissue recurrence in the circumference of the inferior vena cava occurred 2 months

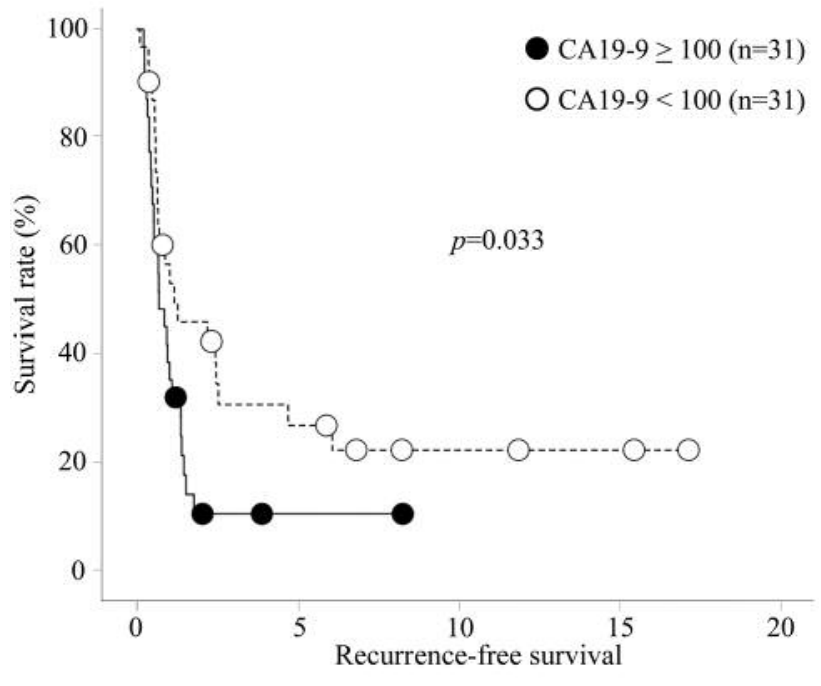

Figure 4. Kaplan-Meier curves of overall survival according to serum CA19-9 levels. Closed circles, CA19-9 high ( $\geq 100 \mathrm{IU} / \mathrm{ml})$ patients. Open circles, CA19-9 low $(<100 \mathrm{IU} / \mathrm{ml})$ patients. $p$-Value was calculated by the log-rank test.

Table I. Clinicopathological characteristics of CA19-9 high and low patient groups.

\begin{tabular}{lccc}
\hline Factors & $\begin{array}{c}\text { CA19-9 high } \\
(\mathrm{n}=31)\end{array}$ & $\begin{array}{c}\text { CA19-9 low } \\
(\mathrm{n}=31)\end{array}$ & $p$-Value \\
\hline Gender (M/F) & $18 / 13$ & $22 / 9$ & 0.213 \\
Age (y.o.) & $68.4 \pm 1.8$ & $68.7 \pm 1.7$ & 0.836 \\
Hepatic virus infection & $24 / 4 / 3 / 0$ & $19 / 8 / 3 / 1$ & 0.405 \\
$((-) / \mathrm{HBV} / \mathrm{HCV} /$ combined $)$ & & & \\
CEA (ng/d) & $5.4(0.8-340)$ & $1.9(0.6-2719)$ & 0.069 \\
Curability (A, B/C) & $23 / 8$ & $29 / 2$ & 0.064 \\
$\mathrm{~T}(1,2 / 3,4)$ & $15 / 16$ & $5 / 26$ & 0.007 \\
$\mathrm{~N}(0 / 1-3)$ & $19 / 12$ & $24 / 7$ & 0.135 \\
cStage (I, II/III, IV) & $5 / 26$ & $12 / 19$ & 0.043 \\
Tumour type (MF/MF $\pm \mathrm{PI})$ & $8 / 23$ & $14 / 17$ & 0.092 \\
Differentiation (well/others) & $7 / 24$ & $9 / 22$ & 0.386 \\
Portal infiltration (-/+) & $15 / 16$ & $23 / 8$ & 0.033 \\
Venous infiltration (-/+) & $26 / 5$ & $27 / 4$ & 1.000 \\
Intrahepatic metastasis $(-/+)$ & $26 / 5$ & $25 / 6$ & 1.000 \\
\hline
\end{tabular}

CA19-9 high: $\geq 100 \mathrm{IU} / \mathrm{ml}$; CA19-9 low: $<100 \mathrm{IU} / \mathrm{ml}$; y.o.: years old; HBV: hepatitis B virus; HCV: hepatitis C virus; CEA: cancer embryonic antigen; MF: mass forming type; cStage: clinical stage; PI: periductal infiltrative type.

after secondary surgery. The patient received chemotherapy (gemcitabine and cisplatin therapy) but died 18 months after primary surgery. Both HDAC1 and HIF- $1 \alpha$ expression were positive. 
Table II. Univariate and multivariate analysis of prognostic factors for overall survival.

\begin{tabular}{|c|c|c|c|c|c|}
\hline \multirow[t]{2}{*}{ Factors } & \multirow[t]{2}{*}{$\mathrm{n} / \mathrm{n}$} & \multicolumn{2}{|c|}{ Univariate } & \multicolumn{2}{|c|}{ Multivariate } \\
\hline & & 5-year OS (\%) & $p$-Value & HR & $p$-Value \\
\hline Gender (M/F) & $40 / 22$ & $32.8 / 34.5$ & 0.896 & & \\
\hline Age $(<60 />60)$ & $10 / 52$ & $45.7 / 29.9$ & 0.488 & & \\
\hline $\operatorname{CEA}(<5 />5))$ & $39 / 22$ & $37.7 / 27.3$ & 0.340 & & \\
\hline Curability (A, B/C) & $52 / 10$ & $37.0 / 11.4$ & 0.073 & 1.100 & 0.827 \\
\hline $\mathrm{T}(1,2 / 3,4)$ & $20 / 42$ & $68.5 / 16.4$ & $<0.001$ & 1.008 & 0.853 \\
\hline $\mathrm{N}(0 / 1-3)$ & $43 / 19$ & $42.9 / 11.3$ & $<0.001$ & 1.663 & 0.178 \\
\hline cStage (I, II/III, IV) & $17 / 45$ & $75.8 / 17.7$ & $<0.001$ & 4.441 & 0.156 \\
\hline Tumour type $(\mathrm{MF} / \mathrm{MF}+\mathrm{PI})$ & $23 / 41$ & $50.6 / 21.9$ & 0.037 & 1.002 & 0.995 \\
\hline Differentiation (well/others) & $16 / 46$ & $32.8 / 33.4$ & 0.703 & & \\
\hline Portal infiltration $(-/+)$ & $38 / 24$ & $42.4 / 17.7$ & 0.001 & 1.505 & 0.265 \\
\hline Venous infiltration $(-/+)$ & $53 / 9$ & $34.7 / 22.2$ & 0.182 & & \\
\hline Intrahepatic metastasis $(-/+)$ & $51 / 11$ & $37.1 / 18.2$ & 0.045 & 1.237 & 0.619 \\
\hline CA19-9 $(<100 />100)$ & $31 / 31$ & $53.8 / 9.4$ & 0.002 & 2.506 & 0.033 \\
\hline
\end{tabular}

HR: Hazard ratio.

Table III. Univariate and multivariate analysis of prognostic factors for recurrence-free survival.

\begin{tabular}{|c|c|c|c|c|c|}
\hline \multirow[t]{2}{*}{ Factors } & \multirow[t]{2}{*}{$\mathrm{n} / \mathrm{n}$} & \multicolumn{2}{|c|}{ Univariate } & \multicolumn{2}{|c|}{ Multivariate } \\
\hline & & 5-year RFS (\%) & $p$-Value & $\mathrm{HR}$ & $p$-Value \\
\hline Gender $(\mathrm{M} / \mathrm{F})$ & $40 / 22$ & $14.6 / 27.2$ & 0.479 & & \\
\hline Age $(<60 />60)$ & $10 / 52$ & $20.0 / 17.4$ & 0.931 & & \\
\hline $\operatorname{CEA}(<5 />5))$ & $39 / 22$ & $18.6 / 19.8$ & 0.730 & & \\
\hline Curability $(\mathrm{A}, \mathrm{B} / \mathrm{C})$ & $52 / 10$ & $22.3 / 0$ & 0.040 & 1.260 & 0.560 \\
\hline $\mathrm{T}(1,2 / 3,4)$ & $20 / 42$ & $50.1 / 2.8$ & $<0.001$ & 0.957 & 0.209 \\
\hline $\mathrm{N}(0 / 1-3)$ & $43 / 19$ & $26.4 / 0$ & $<0.001$ & 1.881 & 0.089 \\
\hline cStage (I, II/III, IV) & $17 / 45$ & $59.3 / 2.6$ & $<0.001$ & 8.746 & 0.012 \\
\hline Tumour type $(\mathrm{MF} / \mathrm{MF}+\mathrm{PI})$ & $23 / 41$ & $37.1 / 7.1$ & 0.027 & 1.160 & 0.678 \\
\hline Differentiation (well/others) & $16 / 46$ & $8.3 / 21.9$ & 0.805 & & \\
\hline Portal infiltration $(-/+)$ & $38 / 24$ & $27.2 / 4.2$ & $<0.001$ & 1.783 & 0.093 \\
\hline Venous infiltration $(-/+)$ & $53 / 9$ & $19.2 / 11.1$ & 0.482 & & \\
\hline Intrahepatic metastasis $(-/+)$ & $51 / 11$ & $22.2 / 0$ & 0.016 & 1.436 & 0.353 \\
\hline CA19-9 $(<100 />100)$ & $31 / 31$ & $27.0 / 10.8$ & 0.033 & 1.436 & 0.313 \\
\hline
\end{tabular}

\section{Discussion}

This study identified serum CA19-9 level as an independent poor prognostic factor for IHCC. Serum CA19-9 levels correlated with both HIF- $1 \alpha$ and HDAC1 expression. HIF$1 \alpha$ and HDAC 1 tended to correlate with each other. These results showed that serum CA19-9 levels reflect the expression of HIF- $1 \alpha$ and HDAC1.

HIF-1 is a transcriptional factor that is induced during hypoxia. HIF-1-regulated genes encode proteins that function in angiogenesis, metabolic reprogramming, extracellular matrix remodelling, epithelial-mesenchymal transition, motility, invasion, metastasis, cancer stem cell maintenance, immune evasion and resistance to chemotherapies $(13,21)$. Previous studies have indicated that HIF-1 may activate CSCs (22-24). We have also reported the correlation between HIF-1 expression and increased CSCs (24). Both HIF-1 and CA19-9 are upregulated during hypoxia (14).

Histone acetylation is a mechanism of epigenetic regulation of gene expression that is downregulated by HDAC family proteins. HDAC 1 is a member of the class I HDAC molecules that have been examined as potential cancer therapeutic targets (25). In general, gene activation correlates with increased acetylated histones. Histone acetylation de-condenses the three- 
a

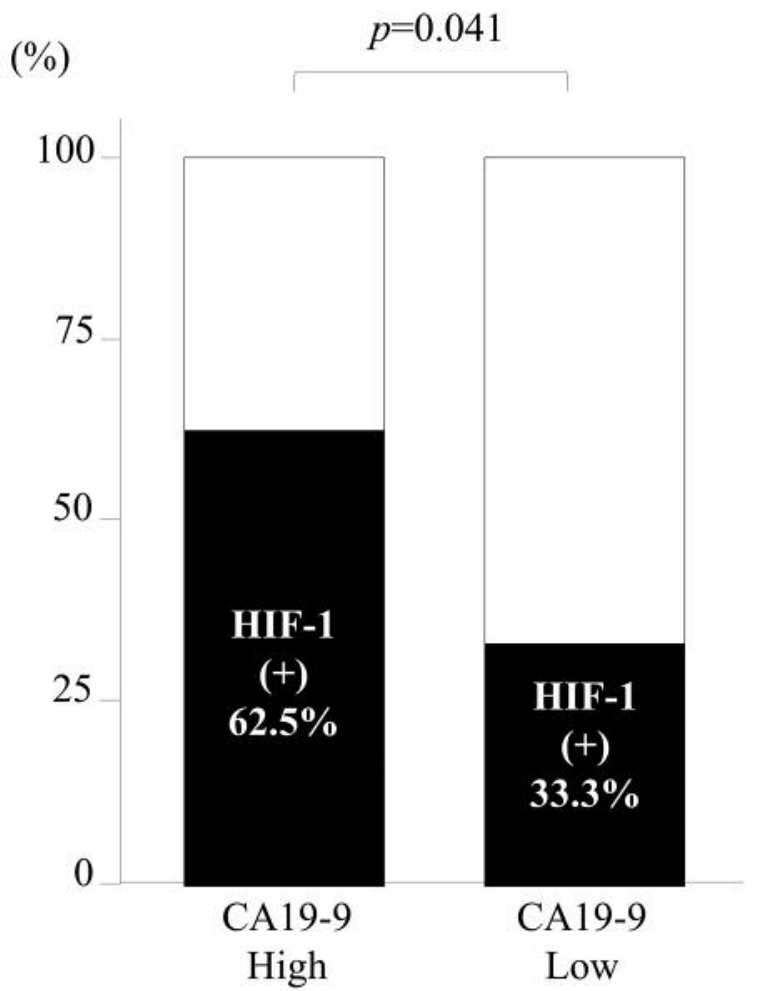

b $(\%)$

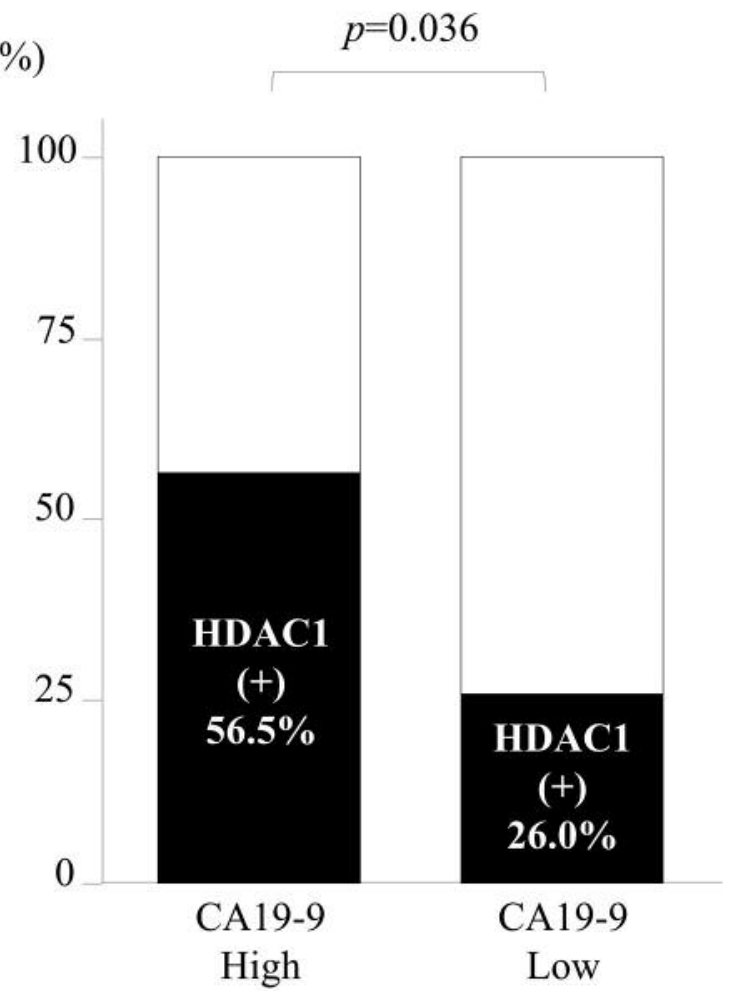

Figure 5. Correlation between serum CA19-9 levels, HIF-1 $\alpha$ and HDAC1 expression in IHCC. Both HIF-1 $\alpha$ and HDAC1 expression significantly correlated with serum CA19-9 level.

dimensional chromatin structure to enable transcriptional factors to bind to DNA. Histone deacetylation induces the condensation of chromatin, leading to inactive chromatin structure $(25,26)$. HDAC1 is necessary for the maintenance of CSCs. HDAC inhibitors including valproic acid have been significantly effective for CSCs phenotypes in ovarian and breast cancer $(27,28)$. We have also reported that HDAC1 expression is related to the existence of CSCs (18).

Our studies have reported the significance of the expression of HIF-1 and HDAC1 in gastroenterological cancer (15, 2932). In colon cancer cells, hypoxic culture and HIFs induced the expression of sialic acid transporters fucosyltransferase and sialyltransferase, which are necessary for the expression of sLea and $\times$ antigen $(33,34)$. We have also previously demonstrated the relationship between HDAC-1 and HIF-1 expression in CSCs $(18,35)$. Taken together, our results suggest that hypoxia may induce HDAC1 and CA19-9 expression via HIF-1 upregulation in IHCC. Thus, serum CA19-9 levels might reflect the existence of CSCs. As shown in representative cases, some IHCC cases with high CA19-9 levels have worse prognosis because of early recurrence.
This study had several limitations. All 62 case specimens could not be evaluated in this study because samples were not available for all cases. Furthermore, we were unable to use the same anti-HDAC1 and anti-HIF-1 $\alpha$ antibodies as in our previous report (17) as they have been discontinued. In addition, the immunohistochemistry methods in the current study were different from our previous report (17). However, our results showing that HDAC1 expression tended to correlate with HIF-1 $\alpha$ expression were similar to our previous results (17). Also, downstream molecules of HDAC1 and HIF-1 $\alpha$, and CSC markers, including CD133 and NANOG, were not investigated. However, based on our previous results (15, $17,18,29,30-32,35)$, high levels of CA19-9 would associate with activation of CSCs.

In conclusion, we showed that high serum CA19-9 level was an independent poor prognostic factor and correlated with both HIF- $1 \alpha$ and HDAC1 expression in IHCC. High serum CA19-9 levels might reflect the increase in CSCs via increased expression of HIF-1 $\alpha$ and HDAC1 due to hypoxia, which are therapeutic molecular targets. 


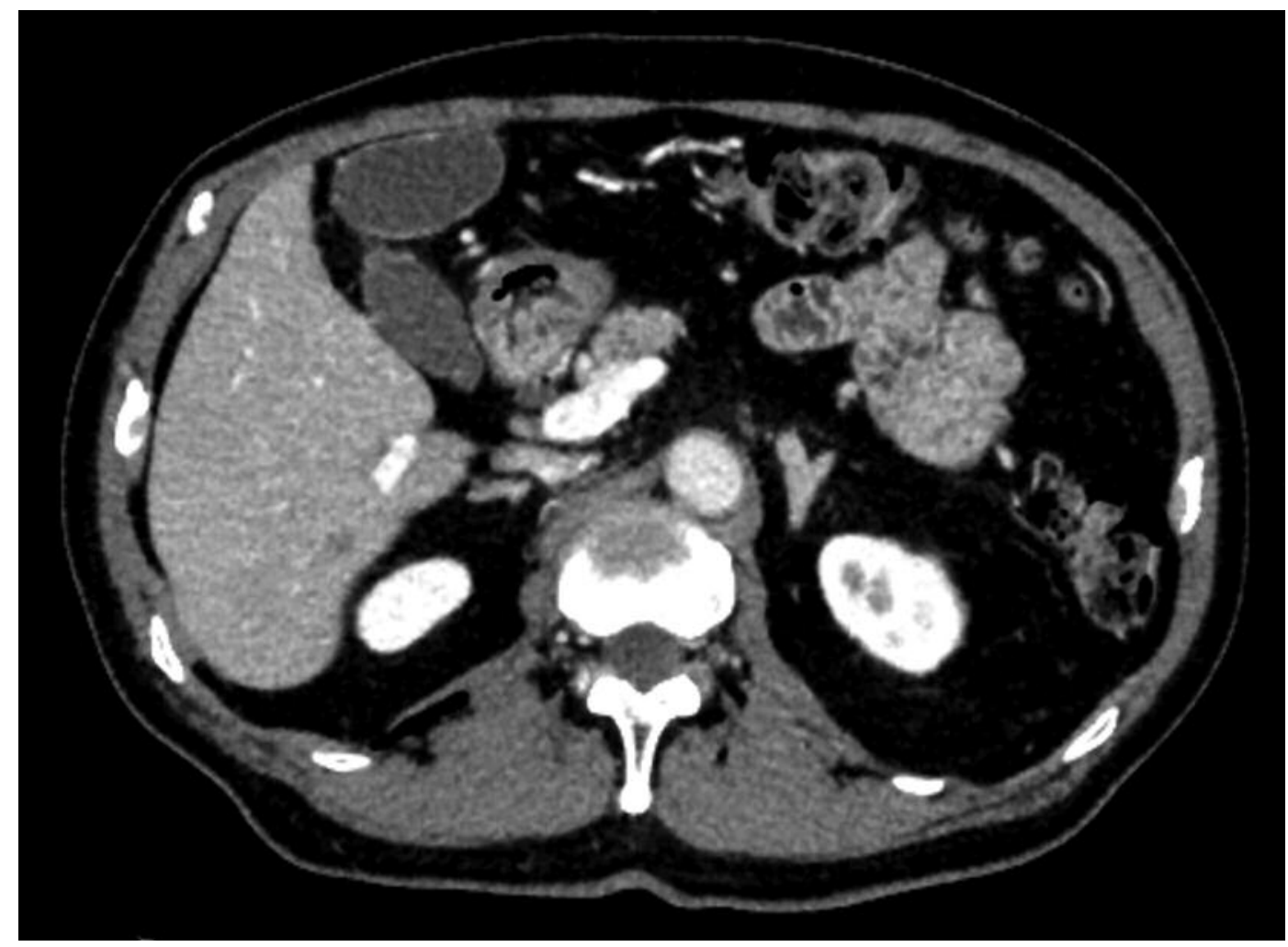

Figure 6. Representative case with high CA19-9levels. Computed tomography imaging revealed a single IHCC of $1.8 \mathrm{~cm}$ in the S6 segment.

\section{Conflicts of Interest}

The Authors declare no conflicts of interests regarding this study.

\section{Authors' Contributions}

S.O. conducted and performed the experiments, analysed data, and wrote the manuscript; M.S., Y.M. designed and planned the experiments; S.I. and T.I. advised in terms of the experimental techniques; Y.A. submitted the application for approval of the clinical research; Y.S., S.Y. and Y.W. checked the clinical and prognostic data in our dataset; S.Y. and Y.B. checked the specimen and performed the pathological evaluation; M.S. checked the experiments and edited the manuscript. All Authors reviewed the manuscript.

\section{Acknowledgements}

The Authors would like to thank the Edanz Group (www.edanzediting.com/ac) for editing a draft of this manuscript.

\section{References}

1 Kudo M, Izumi N, Ichida T, Ku Y, Kokudo N, Sakamoto M, Takayama T, Nakashima O, Matsui O and Matsuyama Y: Report of the 19th follow-up survey of primary liver cancer in Japan.
Hepatol Res 46(5): 372-390, 2016. PMID: 26970231. DOI: 10.1111/hepr.12697

2 Banales JM, Cardinale V, Capino G, Marzioni M, Andersen JB, Invernizzi P, Lind GE, Folseraas T, Forbes SJ, Fouassier L, Geier A, Calvisi DF, Mertens JC, Trauner M, Benedetti A, Maroni L, Vaquero J, Macias RI, Raggi C, Perugorria MJ, Gaudio E, Boberg KM, Marin JJ and Alvaro D: Expert consensus document: Cholangiocarcinoma: current knowledge and future perspectives consensus statement from the European Network for the Study of Cholangiocarcinoma (ENS-CCA). Nat Rev Gastroenterol Hepatol 13(5): 261-280, 2016. PMID: 27095655. DOI: $10.1038 /$ nrgastro.2016.51

3 Zhou JY, Oswald DM, Oliva KD, Kreisman LSC and Cobb BA: The glycoscience of immunity. Trends Immunol 39(7): 523-535, 2018. PMID: 29759949. DOI: 10.1016/j.it.2018.04.004

4 Banales JM, Inarrairaegui M, Arbelaiz A, Milkiewicz P, Muntané J, Muñoz-Bellvis L, La Casta A, Gonzalez LM, Arretxe E, Alonso C, Martínez-Arranz I, Lapitz A, Santos-Laso A, Avila MA, Martínez-Chantar ML, Bujanda L, Marin JJG, Sangro B and Macias RIR: Serum metabolites as diagnostic biomarkers for cholangiocarcinoma, hepatocellular carcinoma and primary sclerosing cholangitis. Hepatology 70(2): 547-562, 2018. PMID: 30325540. DOI: 10.1002/hep.30319

5 Yamada T, Nakanishi Y, Okamura K, Tsuchikawa T, Nakamura T, Noji T, Asano T, Tanaka K, Kurashima Y, Ebihara Y, Murakami S, Shichinohe T, Mitsuhashi T and Hirano S: Impact 
of serum carbohydrate antigen 19-9 level on prognosis and prediction of lymph node metastasis in patients with intrahepatic cholangiocarcinoma. J Gastroenterol Hepatol 33(9): 1626-1633, 2018. PMID: 29427472. DOI: 10.1111/jgh.14124

6 O'Brien DP, Sandanayake NS, Jenkinson C, Gentry-Maharaj A, Apostolidou S, Fourkala EO, Camuzeaux S, Blyuss O, Gunu R, Dawnay A, Zaikin A, Smith RC, Jacobs IJ, Menon U, Costello E, Pereira SP and Timms JF: Serum CA19-9 is significantly upregulated up to 2 years before diagnosis with pancreatic cancer: implications for early disease detection. Clin Cancer Res 21(3): 622-631, 2015. PMID: 24938522. DOI: 10.1158/10780432.CCR-14-0365

7 Chan A, Prassas I, Dimitromanolakis A, Brand RE, Serra S, Diamandis EP and Blasutig IM: Validation of biomarkers that complement CA19.9 in detecting early pancreatic cancer. Clin Cancer Res 20(22): 5787-5795, 2014. PMID: 25239611. DOI: 10.1158/1078-0432.CCR-14-0289

8 Gao Y, Wang J, Zhou Y, Sheng S, Qian SY and Huo X: Evaluation of serum CEA, CA19-9, CA72-4, CA125, and ferritin as diagnostic markers and factors of clinical parameters for colorectal cancer. Sci Rep 8(1): 2732, 2018. PMID: 29426902. DOI: 10.1038/s41598-018-21048-y

9 Wirtz D, Konstantolpulos K and Searson PC: The physics of cancer: the role of physical interactions and mechanical forces in metastasis. Nat Rev Cancer 11(7): 512-522, 2011. PMID: 21701513. DOI: $10.1038 / \mathrm{nrc} 3080$

10 Yamashita S, Passot G, Aloia TA, Chun YS, Javle M, Lee JE, Vauthey JN and Conrad C: Prognostic value of carbohydrate antigen 19-9 in patients undergoing resection of biliary tract cancer. Br J Surg 104(3): 267-277, 2017. PMID: 28052308. DOI: $10.1002 /$ bjs.10415

11 Yamada T, Nakanishi Y, Okamura K, Tsuchikawa T, Nakamura T, Noji T, Asano T, Tanaka K, Kurashima Y, Ebihara Y, Murakami S, Shichinohe T, Mitsuhashi T and Hirano S: Impact of serum carbohydrate antigen 19-9 level on prognosis and prediction of lymph node metastasis in patients with intrahepatic cholangiocarcinoma. J Gastroenterol Hepatol 104(3): 267-277, 2017. PMID: 29427472. DOI: 10.1111/jgh.14124

12 Lee BS, Lee SH, Son JH, Jang DK, Chung KH, Paik WH, Ryu JK and Kim YT: Prognostic value of CA19-9 kinetics during gemcitabine-based chemotherapy in patients with advanced cholangiocarcinoma. J Gastroenterol Hepatol 31(2): 493-500, 2016. PMID: 26220764. DOI: 10.1111/jgh.13059

13 Schito L and Semenza GL: Hypoxia-inducible factors: master regulators of cancer progression. Trends Cancer 2(12): 758-770, 2016. PMID: 28741521. DOI: 10.1016/j.trecan.2016.10.016

14 Kannagi R: Carbohydrate antigen sialyl Lewis a-its pathophysiological significance and induction mechanism in cancer progression. Chang Gung Med J 30(3): 189-209, 2007. PMID: 17760270

15 Morine Y, Shimada M, Utsunomiya T, Imura S, Ikemoto T, Mori H, Hanaoka J, Kanamoto M, Iwahashi $\mathrm{S}$ and Miyake $\mathrm{H}$ : Hypoxia inducible factor expression in intrahepatic cholangiocarcinoma. Hepatogastroenterology 58(110-111): 1439-1444, 2011. PMID: 21940327. DOI: $10.5754 /$ hge 11156

16 Klieser E, Swierczynski S, Mayr C, Schmidt J, Neureiter D, Kiesslich T and Illig R: Role of histone deacetylase in pancreas: implications for pathogenesis and therapy. World J Gastrointest Oncol 7(12): 473-483, 2015. PMID: 26691388. DOI: 10.4251/ wjgo.v7.i12.473
17 Morine Y, Shimada M, Iwahashi S, Utsunomiya T, Imura S, Ikemoto T, Mori H, Hanaoka J and Miyake H: Role of histone deacetylase expression in intrahepatic cholangiocarcinoma. Surgery 151(3): 412-419, 2012. PMID: 21982637. DOI: 10.1016/j.surg.2011.07.038

18 Eto S, Yoshikawa K, Shimada M, Higashijima J, Tokunaga T, Nakao T, Nishi M, Takasu C, Sato $H$ and Kurita N: The relationship of CD133, histone deacetylase 1 and thrombospondin-1 in gastric cancer. Anticancer Res 35(4): 20712076, 2015. PMID: 25862862.

19 The Liver Cancer Study Group of Japan: General Rules for the Clinical and Pathological Study of Primary Liver Cancer. 4th Edition, Kanehara, Tokyo, 2000.

20 Generali D, Berruti A, Brizzi MP, Campo L, Bonardi S, Wigfield S, Bersiga A, Allevi G, Milani M, Aguggini S, Gandolfi V, Dogliotti L, Bottini A, Harris AL and Fox SB: Hypoxia-inducible factor-1alpha expression predicts a poor response to primary chemoendocrine therapy and disease-free survival in primary human breast cancer. Clin Cancer Res 12(15): 4562-4568, 2006. PMID: 16899602. DOI: 10.1158/1078-0432.CCR-05-2690

$21 \mathrm{Lu} \mathrm{X}$ and Kang Y: Hypoxia and hypoxia-inducible factors: master regulators of metastasis. Clin Cancer Res 16(24): 5928-5935, 2010. PMID: 20962028. DOI: 10.1158/1078-0432.CCR-10-1360

22 Mathieu J, Zhang Z, Zhou W, Wang AJ, Heddleston JM, Pinna CM, Hubaud A, Stadler B, Choi M, Bar M, Tewari M, Liu A, Vessella R, Rostomily R, Born D, Horwitz M, Ware C, Blau CA, Cleary MA, Rich JN and Ruohola-Baker H: HIF induces human embryonic stem cell markers in cancer cells. Cancer Res 741(13): 4640-4652, 2011. PMID: 21712410. DOI: 10.1158/ 0008-5472.CAN-10-3320

23 Peng G and Liu Y: Hypoxia-inducible factors in cancer stem cells and inflammation. Trends Pharmacol Sci 36(6): 374-383, 2015. PMID: 25857287. DOI: 10.1016/j.tips.2015.03.003

24 Samanta D, Park Y, Andrabi SA, Shelton LM, Gilkes DM and Semenza GL: PHGDH expression is required for mitochondrial redox homeostasis, breast cancer stem cell maintenance, and lung metastasis. Cancer Res 76(15): 4430-4442, 2016. PMID: 27280394. DOI: 10.1158/0008-5472.CAN-16-0530

25 Tsilimigras DI, Ntansis-Stathopoulos I, Moris D, Spartalis E and Pawlik TM: Histone deacetylase inhibitors in hepatocellular carcinoma: a therapeutic perspective. Surg Oncol 27(4): 611618, 2018. PMID: 30449480. DOI: 10.1016/j.suronc. 2018.07.015

26 Ellmeier W and Seiser C: Histone deacetylase function in CD4+ $\mathrm{T}$ cells. Nat Rev Immunol 18(10): 617-634, 2018. PMID: 30022149. DOI: $10.1038 / \mathrm{s} 41577-018-0037-\mathrm{z}$

27 Witt AE, Lee CW, Lee Tl, Azzam DJ, Wang B, Caslini C, Petrocca F, Grosso J, Jones M, Cohick EB, Gropper AB, Wahlestedt C, Richardson AL, Shiekhattar R, Young RA and Ince TA: Identification of a cancer stem cell-specific function for the histone deacetylases, HDAC1 and HDAC7, in breast and ovarian cancer. Oncogene 36(12): 1707-1720, 2017. PMID: 27694895. DOI: $10.1038 /$ onc.2016.337

28 Pathania R, Ramachandran S, Mariappan G, Thakur P, Shi H, Choi JH, Manicassamy S, Kolhe R, Prasad PD, Sharma S, Lokeshwar BL, Ganapathy V and Thangaraju M: Combined inhibition of DNMT and HDAC blocks the tumorigenicity of cancer stem-like cells and attenuates mammary tumor growth. Cancer Res 76(11): 3224-3235, 2016. PMID: 27197203. DOI: 10.1158/0008-5472.CAN-15-2249 
29 Iwahashi S, Shimada M, Utsunomiya T, Morine Y, Imura S, Ikemoto T, Mori H, Hanaoka J, Sugimoto K and Saito Y: Histone deacetylase inhibitor augments anti-tumor effect of gemcitabine and pegylated interferon- $\alpha$ on pancreatic cancer cells. Int J Clin Oncol 16(6): 671-678, 2011. PMID: 21556798. DOI: $10.1007 /$ s 10147-011-0246-y

30 Batmunkh E, Shimada M, Morine Y, Imura S, Kanemura H, Arakawa Y, Hanaoka J, Kanamoto M, Sugimoto K and Nishi M: Expression of hypoxia-inducible factor-1 alpha in patients with the galbladder carcinoma. Int J Clin Oncol 15(1): 59-64, 2010. PMID: 20082206. DOI: 10.1007/s10147-009-0011-7

31 Yamada S, Utsunomiya T, Morine Y, Imura S, Ikemoto T, Arakawa Y, Kanamoto M, Iwahashi S, Saito Y, Takasu C, Ishikawa D and Shimada M: Expressions of hypoxia-inducible factor-1 and epithelial cell adhesion molecule are linked with aggressive local recurrence of hepatocellular carcinoma after radiofrequency ablation therapy. Ann Surg Oncol 21: S436-42, 2014. PMID: 24566861. DOI: $10.1245 / \mathrm{s} 10434-014-3575-\mathrm{z}$

32 Miyake K, Yoshizumi T, Imura S, Sugimoto K, Batmunkh E, Kanemura H, Morine Y and Shimada M: Expression of hypoxiainducible factor- 1 alpha, histone deacetylase 1 and metastasisassociated protein 1 in pancreatic carcinoma: correlation with poor prognosis with possible regulation. Pancreas 36(3): e1-9, 2008. PMID: 18362831. DOI: 10.1097/MPA.0b013e31815f2c2a

33 Koike T, Kimura N, Miyazaki K, Yabuta T, Kumamoto K, Takenoshita S, Chen J, Kobayashi M, Hosokawa M, Taniguchi
A, Kojima T, Ishida N, Kawakita M, Yamamoto H, Takematsu H, Suzuki A, Kozutsumi Y and Kannagi R: Hypoxia induces adhesion molecules on cancer cells: a missing link between Warburg effect and induction of selectin-ligand carbohydrates. Proc Natl Acad Sci USA 101(21): 8132-8137, 2004. PMID: 15141079. DOI: $10.1073 /$ pnas.0402088101

34 Yin J, Hashimoto A, Izawa M, Miyazaki K, Chen GY, Takematsu H, Kozutsumi Y, Suzuki A, Furuhata K, Cheng FL, Lin CH, Sato C, Kitajima K and Kannagi R: Hypoxic culture induces expression of sialin, a sialic acid transporter, and cancerassociated gangliosides containing non-human sialic acid on human cancer cells. Cancer Res 66(6): 2937-2945, 2006. PMID: 16540641. DOI: 10.1158/0008-5472.CAN-05-2615

35 Shimada M, Sugimoto K, Iwahashi S, Utsunomiya T, Morine Y, Imura $\mathrm{S}$ and Ikemoto $\mathrm{T}$ : CD133 expression is a potential prognostic indicator in intrahepatic cholangiocarcionoma. $\mathbf{J}$ Gastroenterol 45(8): 896-902, 2010. PMID: 20379837. DOI: $10.1007 / \mathrm{s} 00535-010-0235-3$

Received September 24, 2019

Revised October 6, 2019

Accepted October 7, 2019 